https://www.sworldjournal.com/index.php/swj/article/view/swj04-02-017 DOI: 10.30888/2410-6615.2020-04-02-017

\title{
ВЛИЯНИЕ ПАРЕКОКСИБА НАТРИЯ НА КЛЕТКИ КОСТНОГО МОЗГА МЫШЕЙ
}

\section{ACTION OF PAREXOXIB SODIUM ON MOUSE BONE MARROW CELLS}

Ivanov A.S.

Kharkiv State Academy of Postgraduate Education, Kharkiv, Ukraine

Abstract. The use of non-steroidal anti-inflammatory drugs is constantly growing, so it is necessary to create the safest substances, especially for the hematopoietic system. Diclofenac sodium is an active ingredient in many drugs that are selective for cyclooxygenase-2. Studies were conducted on sexually mature laboratory mice at the age of 6 months, weighing 60 grams, in the amount of 44 individuals. The first group received Diclofenac sodium at a dose of $0.09 \mathrm{mg}$, the second $0.18 \mathrm{mg}$, the third saline solution twice a day, 96 hours. Euthanasia was performed under general anesthesia and the bone marrow and cells of the immune system were studied. The effects of Diclofenac sodium at a dose of 0,09 $\mathrm{mg}$ and $0,18 \mathrm{mg}$ have consequences on overall bone marrow status. Decrease in lymphocyte counts I group by $23.9 \%$, II group by $66.1 \%$, neutrophil maturation index I group by 30.2\%, II group by $72.5 \%$ and leukocyte ratio I group by $9.5 \%$, II group by $18 \%$ in comparison with the control group. The total number of bone marrow cells in both groups decreased, and indicators indicating destruction of cell membranes increased. A negative effect was observed regardless of the dose, less in the first group.

Keywords: Bone marrow, Diclofenac sodium, lymphocytes, neutrophil maturation index, erythro-leukocyte ratio.

Among the main buildings of the blood and blood formation system, one of the most important is the maintenance of the internal environment. Achieving this goal is due to the huge number of cells formed in the bone marrow that perform certain highly specialized functions. The formation of the hematopoietic system is carried out long before birth, therefore, hematopoiesis occurs in many organs and systems, but over time this function is fully provided by the bone marrow and lymph nodes $[1,2]$.

Recently, the use of the group of non-steroidal anti-inflammatory drugs (NSAIDs) has increased significantly, which provides constant conditions for creating or searching for all new active substances that have minimal effect on the hematopoiesis system [3]. The range of use of NSAIDs in clinical practice is very large, sometimes a person must take them for a long time, and sometimes for years in order to obtain an anti-inflammatory or analgesic effect [4]. The optimal solution to the question posed today would be the appointment of agents with specificity for cyclooxygenase-2 (COX-2) and minimal toxic effect on the hematopoiesis system, primarily on the bone marrow [5]. Doctors all over the world use NSAIDs that have pronounced and moderate selectivity for $\mathrm{COX}-2$. The active use of these drugs is due to the presence of a pronounced anti-inflammatory effect [6].

The most commonly used drug, which refers to the "gold" standard, is Diclofenac sodium [7]. Many active substances have pronounced analgesic properties, which allows it to be used after surgical interventions in the composition of drugs, especially in patients of an older age group [7]. Diclofenac sodium has found its application in many branches of medicine. It was found that it has selectivity for both forms of COX, this creates the prerequisites for the use of the active substance for the treatment of rheumatic diseases. Recent data indicate that 
diclofenac sodium inhibits COX-2 to a greater extent, as a trigger for the development of the inflammatory process $[8,9]$.

The inhibition of COX-1, which has Diclofenac sodium can cause increased platelet production. It was established that Diclofenac sodium due to inhibition of COX-2 led to an increase in COX-1, which is contained in platelets and increases the risk of blood clots and the development of cardiovascular complications [10, 11]. The question of the effect of Diclofenac sodium on bone marrow and the degree of differentiation of its cells also remains open.

The purpose of the work is to study in experimental conditions the influence of Diclofenac sodium in cells of the bone marrow lymphocytic row of laboratory mice in vivo, provided that it is used for 96 hours.

\section{Materials and methods.}

The experimental part was carried out under conditions of «Ask Health's» Medical and Diagnostic Center LLC, license of the Ministry of Health of Ukraine № 376, dated April 21, 2016, Kharkov, from September 29, 2018 to October 2, 2018, with strict observance of all the rules of humane treatment of experimental animals and asepsis in accordance with the «European Convention for the Protection of Vertebrate Animals for Research or Other Scientific Purposes» (Strasbourg, 1986), the «General Ethical Principles of Animal Experiments» (Kiev, 2001) and the Law Of Ukraine № 3447-IV "On the Protection of Animals from Cruelty" - dated 21.02.2006 [12].

The study was conducted on sexually mature white outbred laboratory mice age of 6 months, weighing 60 grams, in the amount of 44 individuals. The animals were divided into three groups: the first (16 individuals), the second (16 individuals) and the control (12 individuals). The first group received Diclofenac sodium at a dose of $1.5 \mathrm{mg} / \mathrm{kg}$, which in the calculation corresponds to $0.09 \mathrm{mg}$ twice a day for 96 hours. The second group received Diclofenac sodium at a dose of $3 \mathrm{mg} / \mathrm{kg}$, which in the calculation was $0.18 \mathrm{mg}$ twice a day for 96 hours. The control group received physiological saline twice a day for 96 hours. Longer use of Diclofenac sodium led to the death of animals as a result of the development of ulcers in the small intestine and its further perforation. After carrying out the experimental part on day 5, euthanasia was performed by decapitation using Thiopental sodium in an amount of $5 \mathrm{mg} / \mathrm{kg}$ of animal body weight. After euthanasia, the femurs of animals were removed in order to further obtain material for research (bone marrow).

To determine the total number of bone marrow cells, a standard technique for the preparation and undifferentiated blasts study of a bone marrow smear was used [13]. The poppies were stained according to the Romanovsky-Giemsa technique, the myelogram was the number of all bone marrow cells and, counting was performed in the Goryaev's chamber. To isolate a pure cell culture, the method of immunomagnetic separation was used, as the most accurate in which cell loss is $0.01 \%$. To determine the performance of lipopolysaccharides used standard plates (LPS) ELISA Kit for determining mouse lipopolysaccharide. The determination of Antigen-1 (LFA-1) indices was performed after preliminary preparation of the cells; the indicator was determined using flow cytometry technique. The last two indicators determined the degree of damage to the membrane of bone marrow cells. A 
differential calculation was made of the percentage composition of all lymphocytes and the leuko-erythrocyte ratio, which is represented by the ratio of the sum of the percentage of all leukocytes to the total number of nuclear elements of the erythroid series

We analyzed the samples for the presence of normality criteria using the Shapiro-Wilk test (W - value of the Shapiro-Wilk test, $\alpha$ - calculated significance level calculated) [14]. At a calculated significance level of $\alpha_{\text {calc. }}$ more than 0.05 hypothesis was accepted. In order to check the effect of the dose on the average selective indicators, the Kruskal-Wallis test was used $[15,16]$. To check the onedimensional probability distribution, the "box with mustache" type span diagrams were used [16]. To build diagrams and conduct all calculations, the Statistica 10 program was used.

\section{Results}

The results of the study established a clear pattern between the use of Diclofenac sodium and indicators of the total number of bone marrow cells, as well as factors that characterize the degree of damage to cell membranes. The analysis found that, against the background of a decrease in the total number of cells, an increase in the index of undifferentiated blasts and lipopolysaccharides, which may indicate the onset of the inflammatory process and the launch of the cascade of pro-inflammatory cytokines (table 1).

Table 1.

Indicators of the state of the total number of bone marrow cells, total cells, undifferentiated blasts and lipopolysaccharides in group I of mice in vivo using Diclofenac sodium in an amount of $0.09 \mathrm{mg}$ for 96 hours.

\begin{tabular}{|l|l|l|l|l|l|l|l|}
\hline \multirow{2}{*}{ Indicator } & \multicolumn{3}{|l|}{ I group $(\mathrm{n}=16)$} & \multicolumn{3}{l|}{ III group (n=12) } \\
\cline { 2 - 8 } & $\overline{\mathrm{X}}$ & $\delta_{\mathrm{x}}$ & $\Delta_{\mathrm{x}}$ & $\overline{\mathrm{X}}$ & $\delta_{\mathrm{x}}$ & $\Delta_{\mathrm{x}}$ \\
\hline $\begin{array}{l}\text { The total number of bone marrow } \\
\text { cells (cells/ml) } \times 10^{-6}\end{array}$ & 0,4 & 0,1 & 0,05 & 1,1 & 0,1 & 0,05 \\
\hline Undifferentiated blasts (\%) & 5,4 & 0,2 & 0,09 & 2,2 & 0,1 & 0,07 \\
\hline Lipopolysaccharides (ng/ml) & 0,079 & 0,01 & 0,04 & 0,037 & 0 & 0,01 \\
\hline
\end{tabular}

Note: $\overline{\mathrm{X}}$ - average value, $\delta_{\mathrm{x}}-$ standard deviation, $\Delta_{\mathrm{x}}-$ mean square error at the level of 0.05 .

The total number of bone marrow cells in animals of the first group decreased by $67 \%(p<0.05)$. When analyzing the number of undifferentiated blasts, an increase of $145 \%(p<0.05)$ was noted in comparison with the control group. The same trend was observed in lipoplisaccharides, the level of which increased by $113.5 \%$ (p $<0.05)$.

Subsequently, an immunomagnetic separation of bone marrow cells was carried out in order to establish the effect of Diclofenac sodium on individual indicators. We have identified the total number of lymphocytes, as well as calculated the leuko- 
erythrocyte ratio. The level of expression on the surface of lymphocytes, neutrophils and monocytes of Antigen-1 (LFA-1) was also determined. Diclofenac sodium had an effect on all studied groups of cells in the first group of laboratory animals. The smallest changes occurred in the analysis of the indicator of leuko-erythrocyte ratio. The level of expression on Antigen-1 (LFA-1) was significantly higher than that in the homogenates of animal tissue of the control group (table 2).

Table 2.

Indicators of the number of lymphocytes, leuko-erythrocyte ratio and Antigen-1 (LFA-1) of the bone marrow of mice in vivo using Diclofenac sodium at a dose of $0.09 \mathrm{mg}$ for 96 hours.

\begin{tabular}{|c|l|l|l|l|l|l|l|}
\hline \multirow{2}{*}{ Indicator } & \multicolumn{3}{l|}{ I group (n=16) } & \multicolumn{2}{l|}{ III group (n=12) } \\
\cline { 2 - 8 } & $\overline{\mathrm{X}}$ & $\delta_{\mathrm{x}}$ & $\Delta_{\mathrm{x}}$ & $\overline{\mathrm{X}}$ & $\delta_{\mathrm{x}}$ & $\Delta_{\mathrm{x}}$ \\
\hline Lymphocytes (\%) & 16,6 & 0,1 & 0,07 & 22 & 0,2 & 0,1 \\
\hline Leuko-erythropoietic ratio (\%) & 5,16 & 0,2 & 0,09 & 5,7 & 0,1 & 0,08 \\
\hline Antigen-1 (LFA-1) (ng/ml) & 16,4 & 0,2 & 0,1 & 11 & 0,2 & 0,1 \\
\hline
\end{tabular}

Note: $\overline{\mathrm{X}}$ - average value, $\delta_{\mathrm{x}}-$ standard deviation, $\Delta_{\mathrm{x}}-$ mean square error at the level of 0.05 .

The use of Diclofenac sodium in animals of the first group showed a decrease in the studied parameters. The number of lymphocytes was $24.6 \%(p<0.05)$ from similar cells in the control group of animals. The leuko-erythrocyte ratio was the least affected, which amounted to $9.5 \%(\mathrm{p}<0.05)$ of the total cell count in the control group. This may indicate a decrease in the number of elements of leukopoiesis under the influence of Diclofenac sodium. The amount of Antigen-1 in the homogenates of animal tissue of group I increased by $49 \%(\mathrm{p}<0.05)$. This may indicate a decrease in the number of elements of leukopoiesis under the influence of Diclofenac sodium. The amount of Antigen-1 in the homogenates of animal tissue of group I increased by $49 \%(\mathrm{p}<0.05)$.

A different picture was observed in animals of the second group, which received Diclofenac sodium at a dose of $0.18 \mathrm{mg}$. In this case, the total number of bone marrow cells decreased even more. A decrease in the rate of undifferentiated blasts was observed with an increase in the dose of Diclofenac sodium, due to more severe inhibition of stem cell factor and interleukin-6. Only the rate of lipopolysaccharides increased, which indicates inflammation in the bone marrow (Table 3).

The results of the study indicate the presence of a negative effect of Diclofenac sodium in an amount of $0.18 \mathrm{mg}$ on the total number of bone marrow cells. In animals of group II, the total cell count decreased by $90.9 \%(p<0.05)$. Toxicly, an increase in the dose of Diclofenac sodium affected the rate of undifferentiated blasts, the rate of which decreased by $63.6 \%(\mathrm{p}<0.05)$. an increase in the number of lipopolysaccharides in bone marrow homogenates was observed, by $1872.9 \%$ $(\mathrm{p}<0.05)$. 
Table 3.

Indicators of the state of the total number of bone marrow cells and cell wall destruction factors in group I of mice in vivo using Diclofenac sodium in an amount of $0.18 \mathrm{mg}$ for 96 hours.

\begin{tabular}{|l|l|l|l|l|l|l|}
\hline \multirow{2}{*}{ Indicator } & \multicolumn{3}{|l|}{ II group (n=16) } & \multicolumn{3}{l|}{ III group (n=12) } \\
\cline { 2 - 8 } & $\overline{\mathrm{X}}$ & $\delta_{\mathrm{x}}$ & $\Delta_{\mathrm{x}}$ & $\overline{\mathrm{X}}$ & $\delta_{\mathrm{x}}$ & $\Delta_{\mathrm{x}}$ \\
\hline $\begin{array}{l}\text { The total number of bone marrow } \\
\text { cells (cells/ml) } \times 10^{-6}\end{array}$ & 1 & 0,1 & 0,07 & 1,1 & 0,1 & 0,05 \\
\hline Undifferentiated blasts (\%) & 0,8 & 0,1 & 0,04 & 2,2 & 0,1 & 0,07 \\
\hline Lipopolysaccharides (ng/ml) & 0,73 & 0,2 & 0,1 & 0,037 & 0 & 0,01 \\
\hline
\end{tabular}

Note: $\overline{\mathrm{X}}$ - average value, $\delta_{\mathrm{x}}-$ standard deviation, $\Delta_{\mathrm{x}}-$ mean square error at the level of 0.05 .

Changes were also observed in the indicator of lymphocytes, leuko-erythrocyte ratio and Antigen-1 (LFA-1). A decrease in all cellular parameters was observed, while the level of expression of Antigen-1 (LFA-1) on the surface of lymphocytes, neutrophils and monocytes increased. The dose of $0.18 \mathrm{mg}$ Diclofenac sodium had a significant effect (table 4).

Table 4.

Indicators of the number of lymphocytes, leuko-erythrocyte ratio and Antigen-1 (LFA-1) of the bone marrow of mice in vivo using Diclofenac sodium at a dose of $0.18 \mathrm{mg}$ for 96 hours.

\begin{tabular}{|c|l|l|l|l|l|l|}
\hline \multirow{2}{*}{ Indicator } & \multicolumn{3}{l|}{ II group $(\mathrm{n}=16)$} & \multicolumn{3}{l|}{ III group (n=12) } \\
\cline { 2 - 8 } & $\overline{\mathrm{X}}$ & $\delta_{\mathrm{x}}$ & $\Delta_{\mathrm{x}}$ & $\overline{\mathrm{X}}$ & $\delta_{\mathrm{x}}$ & $\Delta_{\mathrm{x}}$ \\
\hline Lymphocytes (\%) & 7,5 & 0,1 & 0,06 & 22 & 0,2 & 0,1 \\
\hline Leuko-erythropoietic ratio (\%) & 5 & 0 & 0,04 & 5,7 & 0,1 & 0,08 \\
\hline Antigen-1 (LFA-1) (ng/ml) & 13 & 0,2 & 0,1 & 11 & 0,2 & 0,1 \\
\hline
\end{tabular}

Note: $\overline{\mathrm{X}}-$ average value, $\delta_{\mathrm{x}}-$ standard deviation, $\Delta_{\mathrm{x}}-$ mean square error at the level of 0.05 .

An analysis of the percentage of the total number of lymphocytes and leukoerythropoietic ratio of the brain of cats in animals of group II showed a significant effect of Diclofenac sodium at a dose of $0.18 \mathrm{mg}$. A decrease in the rate of lymphocytes was found to be $66 \%(\mathrm{p}<0.05)$, while the leuko-erythroid ratio was lower by $12.3 \%(\mathrm{p}<0.05)$. The level of expression on the surface of neutrophils, macrophages and lymphocytes, Antigen-1 (LFA-1) increased by $18.2 \%(\mathrm{p}<0.05)$. The data obtained may sat in favor of the development of an anemic condition. 
When analyzing changes in the total number of bone marrow cells, it was found that the use of Diclofenac sodium led to more significant changes in the second group by $90.9 \%$, while in the first group the indicator was lower by $67.3 \%(\mathrm{p}<0.05)$. The level of undifferentiated flippers in the first group increased by $145.4 \%$, while in the second group the number of cells decreased by $63.6 \%(\mathrm{p}<0.05)$. the concentration of lipopolysaccharides in tissue homogenates of the first group of animals increased by $113.5 \%$, while in the second by $1872.9 \%(\mathrm{p}<0.05)$, which indicates the development of toxicity in the second group.

When analyzing lymphocytes and the leuko-erythroid ratio, the negative effect of Diclofenac sodium on the bone marrow, as an active substance, was established. In the first group, the number of cells decreased by $24.6 \%$, while in the second by $66 \%$ $(\mathrm{p}<0.05)$. the leuko-erythroid ratio in the first group turned out to be lower by $9.5 \%$, in the second by $12.3 \%$ due to cells of the leukocyte series. The highest expression of the level of Antigen-1 (LFA-1) was observed in tissue homogenates of the first group by $49 \%$, while in the second it was only $18.2 \%(\mathrm{p}<0.05)$ more than in the control.

Next, we analyzed the samples studied during the experiment for the presence of a normal distribution (table 5).

Table 5.

Testing the hypothesis of normality of data distribution.

\begin{tabular}{|c|c|c|c|c|c|c|}
\hline \multirow[t]{2}{*}{ Variable } & \multicolumn{2}{|l|}{ I group } & \multicolumn{2}{|c|}{ II group } & \multicolumn{2}{|c|}{ Control } \\
\hline & $\mathrm{W}$ & $\alpha_{\text {calc. }}$ & $\mathrm{W}$ & $\alpha_{\text {calc. }}$ & W & $\alpha_{\text {calc. }}$ \\
\hline $\begin{array}{l}\text { The total number of } \\
\text { bone marrow cells }\end{array}$ & 0,8305 & 0,0071 & 0,8980 & 0,0747 & 0,8025 & 0,01 \\
\hline $\begin{array}{l}\text { Undifferentiated } \\
\text { blasts }\end{array}$ & 0,9543 & 0,5613 & 0,8077 & 0,0035 & 0,9337 & 0,4208 \\
\hline Lipopolysaccharides & 0,9630 & 0,7170 & 0,7315 & 0,0004 & 0,9253 & 0,3326 \\
\hline Lymphocytes & 0,9290 & 0,2350 & 0,9144 & 0,1368 & 0,9115 & 0,2230 \\
\hline $\begin{array}{l}\text { Leuko-erythropoietic } \\
\text { ratio }\end{array}$ & 0,2777 & 0 & 0,8844 & 0,0454 & 0,9056 & 0,1874 \\
\hline Antigen-1 (LFA-1) & 0,9409 & 0,3598 & 0,9733 & 0,8877 & 0,9101 & 0,2139 \\
\hline
\end{tabular}

Note: $\mathrm{W}$ - value of the Shapiro-Wilk criterion, $\alpha_{\text {calc. }}$ - calculated level of value.

As the above data show, in some cases the normality hypothesis is discarded (table 5). This is traced for the index of the total number of bone marrow cells, where I group (W - 0.8305; $\left.\alpha_{\text {calc. }}-0,0071\right)$, control (W - 0,8025; $\left.\alpha_{\text {calc. }}-0.01\right)$, undifferentiated blasts, where in the II group (W - 0,8077; $\left.\alpha_{\text {calc. }}-0,0035\right)$ and lipopolysaccharides in that's group (W $\left.-0,7315 ; \alpha_{\text {calc. }}-0,0004\right)$. The indicator of leuko-erythrocyte ratio for I group (W - 0,$2777 ; \alpha_{\text {calc }}-0$ ), II group (W - 0,$8844 ; \alpha_{\text {calc }}$ 0,0454). This fact makes it impossible to use parametric methods for further analysis; therefore, nonparametric statistics methods were further used. For this, it is necessary to check the effect of the dose on the average sample indicators of the studied samples according to the non-parametric rank criterion of Kruskal-Wallis.

The results of checking the presence or absence of equality of median samples at three levels: I group, II group and control (table 6). 
Table 6.

Testing the meridian equality hypothesis for samples at Diclofenac sodium control $\left(n_{1}=12\right)$, I group $\left(n_{2}=16\right)$ II group $\left(n_{3}=16\right)$. The value of $H_{\text {cr. }}=X^{2}{ }_{\text {cr. }}(0,05 ; 2)$ $=\mathbf{5 , 9 9 1 4}$.

\begin{tabular}{|l|l|l|c|}
\hline Variable & $H_{\text {emp. }}$ & $\alpha_{\text {cr. }}$ & $\begin{array}{l}\text { Decision to accept the } \\
\text { meridian equality hypothesis }\end{array}$ \\
\hline $\begin{array}{l}\text { The total number of } \\
\text { bone marrow cells }\end{array}$ & 38,4 & $<10^{-4}$ & Discarded \\
\hline $\begin{array}{l}\text { Undifferentiated } \\
\text { blasts }\end{array}$ & 38,3 & $<10^{-4}$ & Discarded \\
\hline Lipopolysaccharides & 38,1 & $<10^{-4}$ & Discarded \\
\hline Lymphocytes & 35,8 & $<10^{-4}$ & Discarded \\
\hline $\begin{array}{l}\text { Leuko- } \\
\text { erythropoietic ratio }\end{array}$ & 38,3 & $<10^{-4}$ & Discarded \\
\hline Antigen-1 (LFA-1) & 38,2 & $<10^{-4}$ & Discarded \\
\hline
\end{tabular}

The data obtained indicate that in all cases the hypothesis of equality of the medians is rejected for all variables (table 5). Based on this fact, we can make an assumption about the significant effect of the used dose of Diclofenac sodium on indicators of the total number of bone marrow cells, indicator of undifferentiated blasts, leuko-erythroid ratio and lymphocytes, lipopolysaccharides and antigen-1 expression in the first and second groups of laboratory mice in vivo.

Assuming that three equally spaced (abscissa) dose values can be placed on the span diagram, this will allow us to get an idea of the trends in the effect (median values of the variables in table 6) from the dose in the range 0, 50 and $100 \%$ (Diagrams 1-6).

Diagram 1. The total number of bone marrow cells Diagram 2. Lipopolysaccharides

(COX 5)

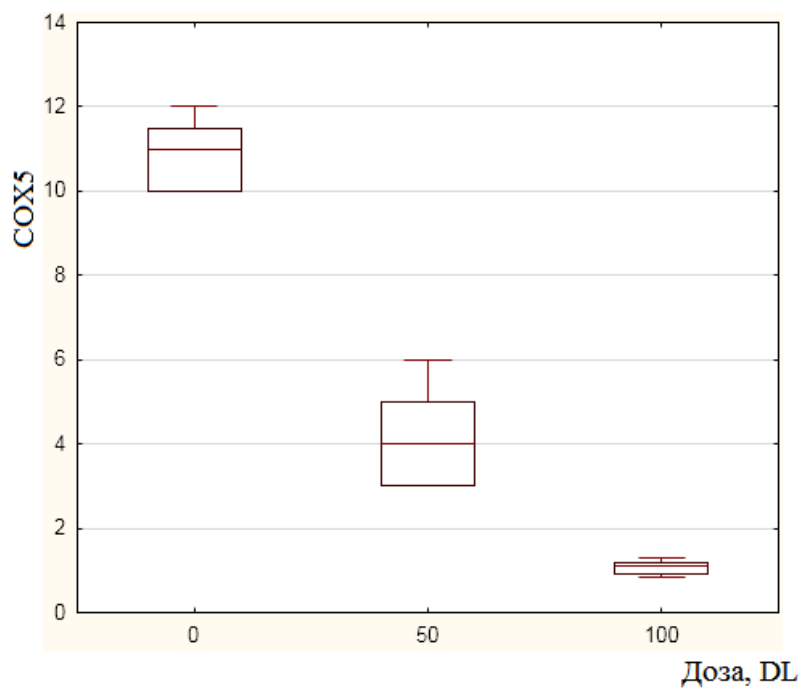

(COX 6)

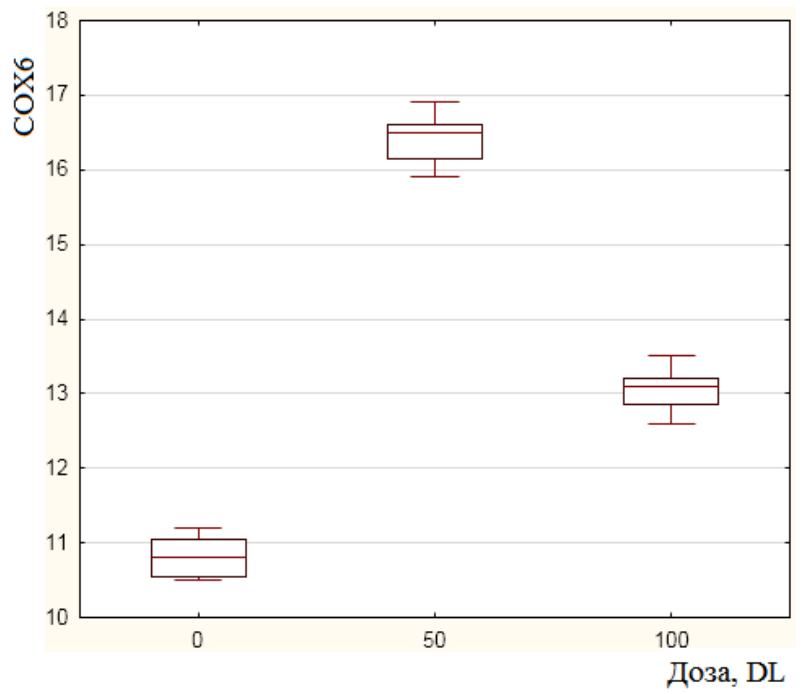


Diagram 3. Antigen-1 (LFA-1) (COX 2)

Diagram 4. Lymphocytes (My 8).
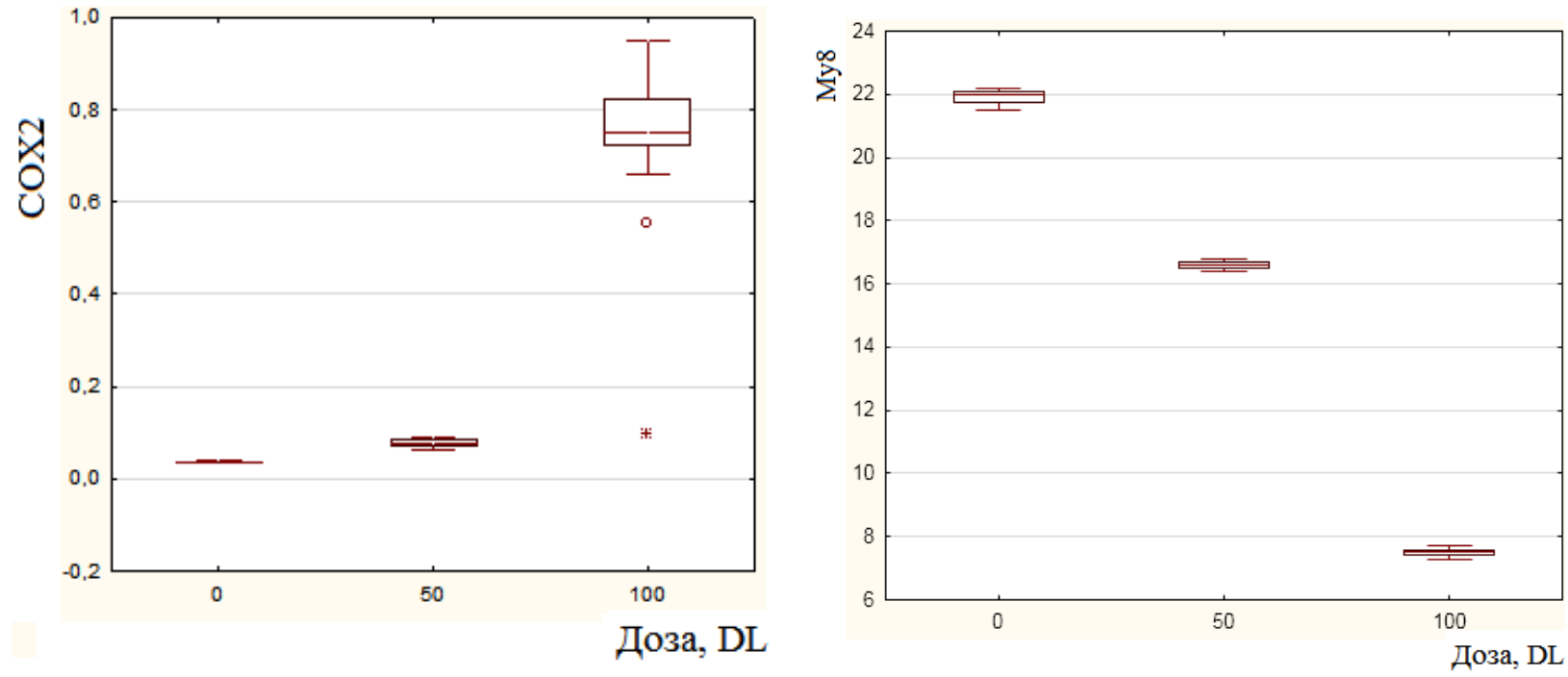

Diagram 5. Neutrophil maturat. ind. (My9) Diagram 5. Leuko-erythropoietic ratio (My 11).
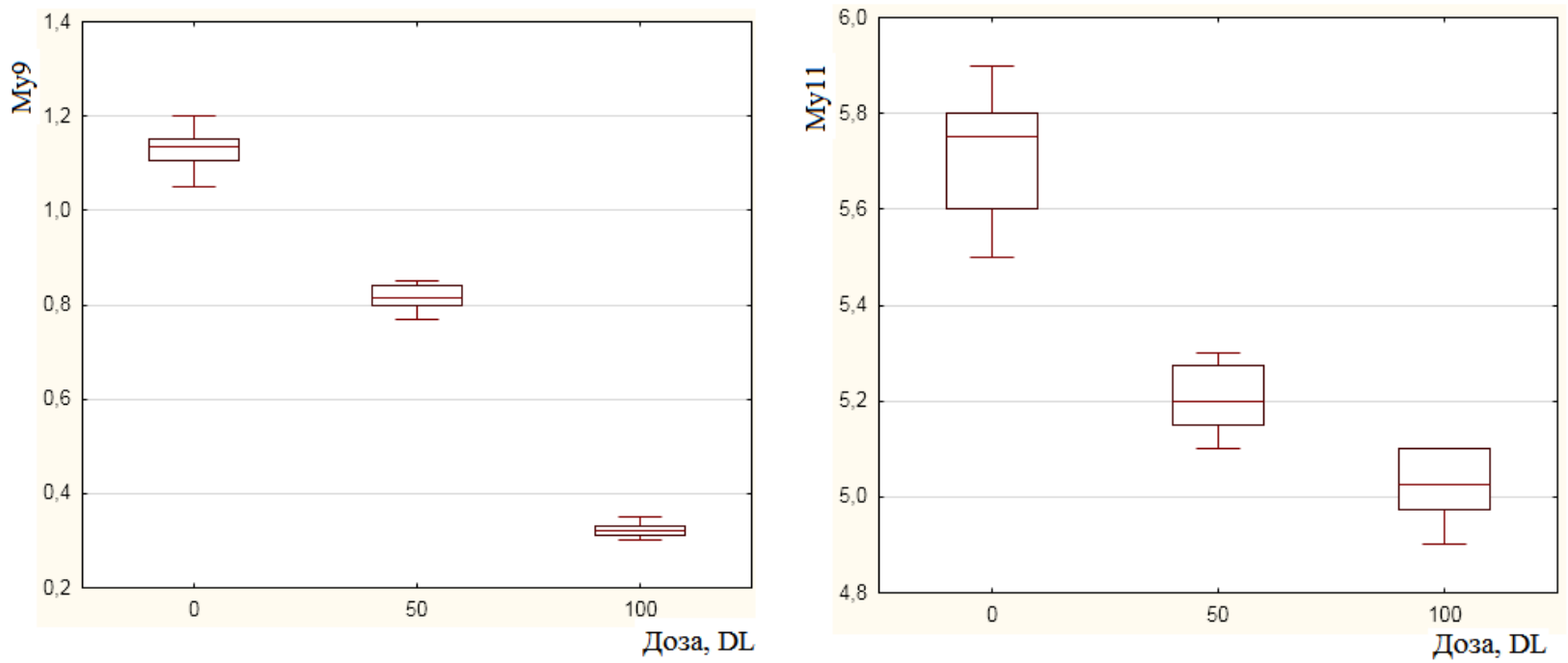

Designations:

Median

$25-75 \%$

Span without ejection

The presented span diagrams demonstrate the absence of intersection of a straight line drawn vertically through the "boxes". This confirms the conclusion that the dose of Diclofenac sodium affects the number of bone marrow cells, undifferentiated blasts, lipopolysaccharides, Antigen-1, as well as lymphocytes, and leuko-erythrocyte ratio. An almost linear increase in the curve is observed with increasing doses of the test substance. An analysis of the diagrams also allows us to establish that the nonlinear variable is maximum in diagram № 2,5 for animals of the first group, nonlinear increase with increasing dose is observed in diagram № 3, 
almost linear in diagram № 4 .

An additional idea of the state of the studied parameters under the influence of Diclofenac sodium can give a graph (graphs № 1,2).

Chart 1.

Indicators of the total number of bone marrow cells, factors characterizing damage to the cell membrane of bone marrow cells of mice in vivo under the influence of

Diclofenac sodium for 96 hours.

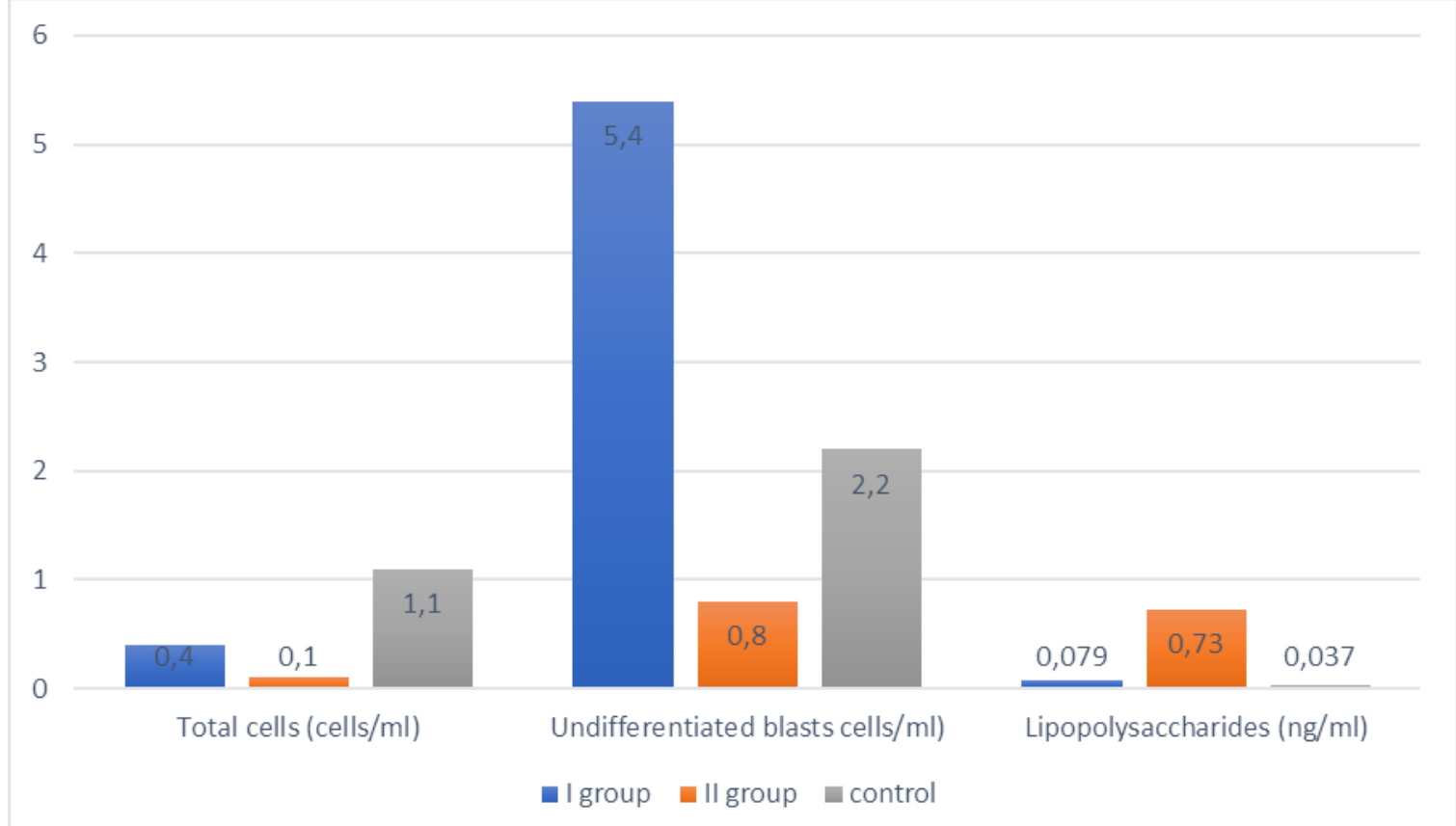

Chart 2.

Indicators of lymphocytes, neutrophil maturation index, and leuko-erythrocyte ratio of bone marrow cells of mice in vivo under the influence of Diclofenac sodium for 96

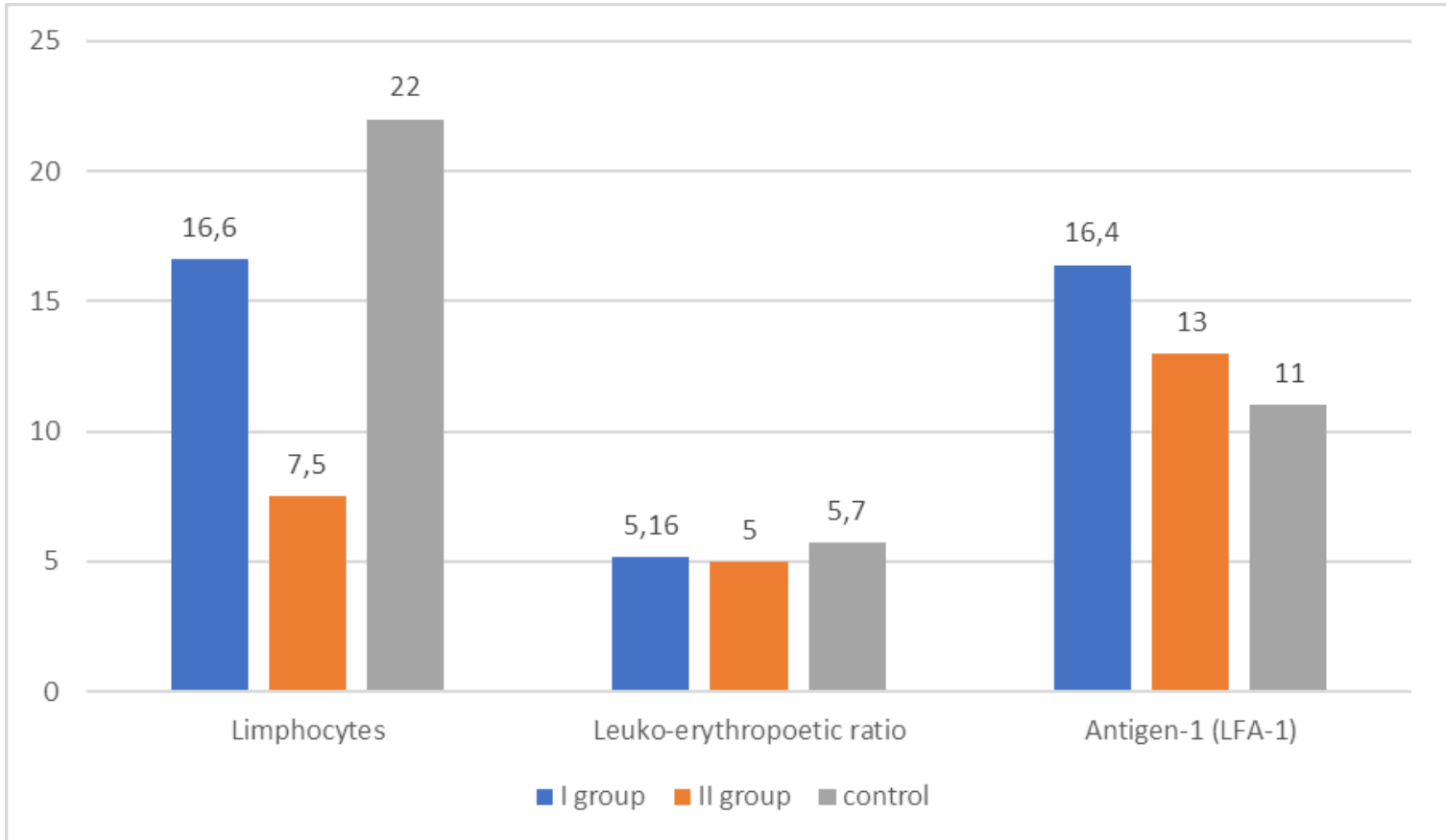

hours. 


\section{Conclusion}

An analysis of the results of the study suggests that the use of Diclofenac sodium at a dose of 0.18 and $0.09 \mathrm{mg}$ led to a negative effect on the total number of bone marrow cells in vivo in mice, undifferentiated blasts, lipopolysaccharides and Antigen-1, the total number of lymphocytes, leuko-erythrocyte ratio. The most favorable effect was exerted by a dose of $0.09 \mathrm{mg}$ on the parameters studied during the study. More significant changes were observed in animals that received $0.18 \mathrm{mg}$, the number of bone marrow cells decreased significantly, as well as the number of lymphocytes, undifferentiated blasts, leuko- erythropoietic ratio, which may indicate the development of an anemic condition. An increase in the level of lipopolysaccharides may indicate an inflammatory process in connection with an increase in dose. The level of expression of Antigen-1 (LFA-1) was the highest in group II, which may indicate maximum activation of the immune system at a given dose.

\section{Literature}

1. Danilova I. H., Yushkov B. H., Ulitko M.V. et all. Vliyanie systemy fagotsytyruiushchikh mononuklearov na eritropoez $\mathrm{v}$ eritroblasticheskikh ostrovkakh kostnoho mosha (The influence of the system of phagocytic mononuclear cells on erythropoiesis in erythroblastic islets of the bone marrow). Meditsinskaia immunolohiia. Vol. 8, № 2/3 (2006). P. 135-145 [in Russian].

2. Leontiuk A.S., Sluka B.A. Osnovy vozrastnoy histologii (The basics of agerelated histology). Vysshaia shkola, Minsk, Belarus, 2000, P. 418 [in Russian].

3. Deryvedmid L.V., Veretinova V.P. Kombinovany khondroprotektory pry likuvanni osteoartrytu (Combined chondroprotectors in the treatment of osteoarthritis). Bil, suhloby, khrebet. Vol.8, № 1 (2018). P. 31-36 [in Ukrainian].

4. Hryshchenko A. V. Hematologichnyi profil u shchuriv pry eksperymentalnomu dyklofenak-indukovanomu hepatyti (Hematological profile in rats in experimental diclofenac-induced hepatitis). Ukrainian Journal of Ecology. Vol. 7(3) (2017). P.78-83 [in Ukrainian].

5. Seliuk M.N., Kozachok N.N., Seliuk O.V. Novye hrani klassicheskoho nesteroidnoho protivovospalitelnoho sredstva diklofenak (New facets of the classic non-steroidal anti-inflammatory drug diclofenac). Suchasni preparaty ta tekhnolohii. Vol. 8 (104) (2013). P 35-40 [in Russian].

6. Kursov S.V., Nikonov V.V. TSIKLOOKSIGENAZA: fiziologicheskie effekty, deistvie inhibitorov i perspektivy dalneisheho ispolzovaniia paratsetamola (analiticheskiy obzor) (CYCOOXYGENASE: physiological effects, the action of inhibitors and the prospects for further use of paracetamol (analytical review)). Meditsina neotlozhnykx sostoyaniy.Vol. 5(76) (2016). P. 27-35 [in Russian].

7. Ponomarev V.V., Baranova E.V. Transdermalnoe priminenie diklofenaka pri khronicheskoi dorsopatii $\mathrm{v}$ kontekste istorii sozdaniyai mekhanizmov deystvia preparata (Transdermal use of diclofenac in chronic dorsopathy in the context of the history of the creation and mechanisms of action of the drug). Meditsinskie novosty. 2017. №2. P. 51-54 [in Russian]. 
8. Podobed V.M., Hrintsevich A.V. Opyt klinicheskoho primeneniya lekarstvennykh sredstv (Experience in the clinical use of drugs). Vestnyk farmatsii. 2014. №3(65).

P. 105-112 [in Russian].

9. Danylov A.B. Diklofenac v lechenii bolevykh syndromov (Diclofenac in the treatment of pain). Lechashiy vrach. 2009. №5. P. 58-63 [in Russian].

10. Ehorov I.V., Tsurko I.V., Tsurko V.V. Ratsionalnye podkhody i sovremennaya terapiya ostroho i khronicheskoho bolevoho sindroma: pol i mesto NPVS (Rational approaches and modern therapy of acute and chronic pain syndrome: the role and place of NSAIDs). Farmakokinetika. 2008. №15. P. 54-59 [in Russian].

11. Orinya Agbaji Orinya, Adeshina Yahaya Adenkola, Raphael John Ogbe. Haematological and biochemical studies on the effect of diclofenac sodium on Wistar Rattus norvegicus. International Journal of Biological and Chemical Sciences. 2016. Vol. 10(5). P. 2231-2242.

12. Helsinska Deklaratsiia Vsesvitnoi medychnoi asotsiatsii (Helsinki Declaration of the World Medical Association). Morfologia. Vol. 4(2) (2010). P.6585 [in Ukrainian].

13. Volkova O.V., Eletskii Yu. K. Osnovy histolohii s histolohicheskoi tekhnikoi (Basics of histology with histological technique). Meditsina, Moskow, USSR, 1971, P. 415 [in Russian].

14. Kobzar A.I. Prykladnaia matematicheskaya statistika. Dlya injenerov $i$ nauchnykh rabotnikov (Applied Mathematical Statistics. For engineers and scientists). FIZMATLIT, Moskow, Russia, 2006, P. 816 [in Russian].

15. Lahutin M.B. Nahladnaia matematicheskaia statistika (Visual math statistics). BINOM. Laboratoriia znanii Moskow, Russia, 2015, P. 475 [in Russian].

16. Potter, K., Hagen, H., Kerren, A., \& Dannenmann, P. (2006). Methods for presenting statistical information: The box plot. Visualization of large and unstructured data sets, 4, 97-106. 